Received 25.02.2019

Reviewed $\quad 25.03 .2019$

Accepted $\quad 07.05 .2019$

A - study design

B - data collection

C - statistical analysis

D - data interpretation

E - manuscript preparation

F - literature search

\section{Current status and perspectives} on offshore wind farms development in the United Kingdom

\author{
Leszek DAWID ${ }^{\mathrm{ABCDEF} \otimes}$
}

orcid.org/0000-0002-7939-1598; Technical University of Koszalin, Faculty of Civil Engineering, Environmental and Geodetic Sciences, ul. Śniadeckich 2, 75-453 Koszalin, Poland; e-mail: leszek.dawid@tu.koszalin.pl

For citation: Dawid L. 2019. Current status and perspectives on offshore wind farms development in the United Kingdom. Journal of Water and Land Development. No. 43 (X-XII) p. 49-55. DOI: 10.2478/jwld-2019-0062.

\begin{abstract}
The purpose of the article is to present perspectives for the development of offshore wind farms in the leading, in this respect, country in the EU and in the world - Great Britain. Wind power plays a remarkable role in the process of ensuring energy security for Europe since in 2016 the produced wind energy met $10.4 \%$ of the European electricity demand while in 2017 it was already around $11.6 \%$. The article analyses the capacity of wind farms, support systems offered by this country and the criteria related to the location of offshore wind farms. The research has been based on the analysis of legal acts, regulations, literature on the subject, information from websites. The article shows that in recent years, the production of energy at sea has been developing very rapidly, and the leading, in this matter, British offshore energy sector is characterised by strong governmental support.
\end{abstract}

Key words: energy production, offshore wind farms, renewable energy sources, wind energy

\section{INTRODUCTION}

Renewable energy is playing an increasingly important role in the EU's energy system. In the year 2017, it accounted for as much as $85 \%$ of the installed new capacity to reach $95 \%$ year later [WindEurope 2018b; WindEurope $2019 \mathrm{~b}$ ]. From the total of $28.3 \mathrm{GW}$ and $20.7 \mathrm{GW}$ of the new power in 2017 and 2018, 23.9 GW and 19.8 GW were renewable energy. Wind energy was the most significant both in 2017 and 2018 as it constituted as much as 55.2\% $(15.64 \mathrm{GW})$ and $49 \%(10.1 \mathrm{GW})$ of installed new capacity, respectively. In 2017 the wind was followed by solar energy $21.3 \%(6.03 \mathrm{GW})$, natural gas $9.2 \%(2.61 \mathrm{GW})$, coal $6.1 \%(1.74 \mathrm{GW})$, from hydroelectric power plants $3.8 \%$ $(1.09 \mathrm{GW})$, from biomass $3.4 \%(0.96 \mathrm{GW})$, and other remaining $0.9 \%(0.25 \mathrm{GW})$ as shown in Fig. 1a. In 2018 shares were similar, however coal contributed only 0.2 GW (1\%) to new installed capacity (Fig. 1b). Furthermore, wind energy plays a significant role in the process of ensuring energy security for Europe because in terms of generated energy, in 2016 the wind contributed to the produc- tion of approx. 300 TWh [PSEW 2016] electricity, in 2017 to around $336 \mathrm{TWh}$, and reached $362 \mathrm{TWh}$ in 2018 [WindEurope 2018b; WindEurope 2019b]. The produced energy met $10.4 \%, 11.6 \%$ and $14.0 \%$ of the EU's electricity demand, respectively. Investments in the construction of wind farms may also help, to a significant extent, in the reduction of greenhouse gases and thus in the implementation of the EU's policy in this realm [Directive 2001/77/EC; 2003/30/EC; 2009/28/EC]. WindEurope [2019b] estimates that with a total installed capacity of $178.8 \mathrm{GW}$ in the EU, wind energy is likely to overtake natural gas installations in 2019, while nowadays remains the second largest form of power generation capacity in the EU.

Within the EU, there has been an annual increase in energy capacity from onshore and offshore wind farms. In 2010 , the added power amounted to approx. $10 \mathrm{GW}$. In 2017, 15.6 GW of power was added (Fig. 2). The offshore wind energy is beginning to play an increasingly important role. The European Union is the leader in the area of offshore wind energy and every year is marked with a remarkable growth of this sector. In 2010, around 
a)

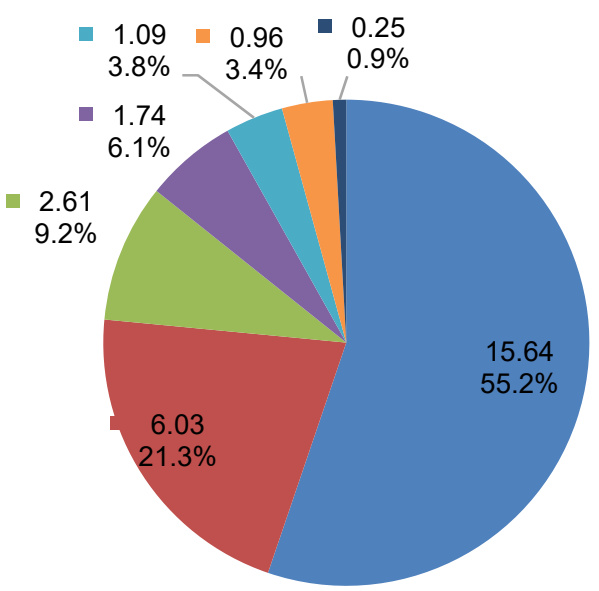

b)

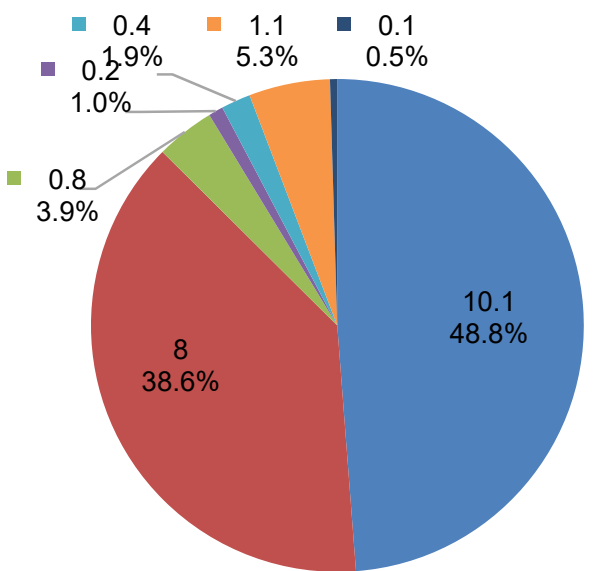

- Wind

Natural gas

- Solar power

Hydroelectric power plants

- Others

Fig. 1. Power increase in GW and percentage in the EU from renewable and conventional sources: a) in 2017, b) in 2018; source: own elaboration based on WindEurope [2018b]

$0.9 \mathrm{GW}$ of power was added, in 2017 it was as much as 3.1 GW. Winds blowing over the sea are stronger and more stable than those over the land. Thanks to this, offshore wind farms provide more power per unit area than land based farms [BWE 2017]. Turbines can be larger, they are easier to transport to the installation site. Their construction does not raise such negative emotions in the society as onshore wind farms [DAWID 2017a, b; 2018a, b; STRYJECKI et al. 2011]. However, they are more expensive than onshore wind farms [Odnawialne-Firmy.pl 2014]. New technologies, however, make them gradually more affordable. Nevertheless, the investments related to their construction are huge. The average cost of building a wind farm is approximately $4 \mathrm{mln}$ EUR per $1 \mathrm{MW}$ of installed capacity [McKinsey\&Company 2016]. In the EU in 2010 a total of 16.5 bln EUR was spent - including $8.4 \mathrm{bln}$ on the construction of offshore wind farms. In 2017, it was already 22.3 bln EUR, including 7.5 bln EUR on offshore wind farms (Fig. 3). The largest investments in the construction of offshore wind farms were made in 2016 - approx. 18.2 bln EUR.

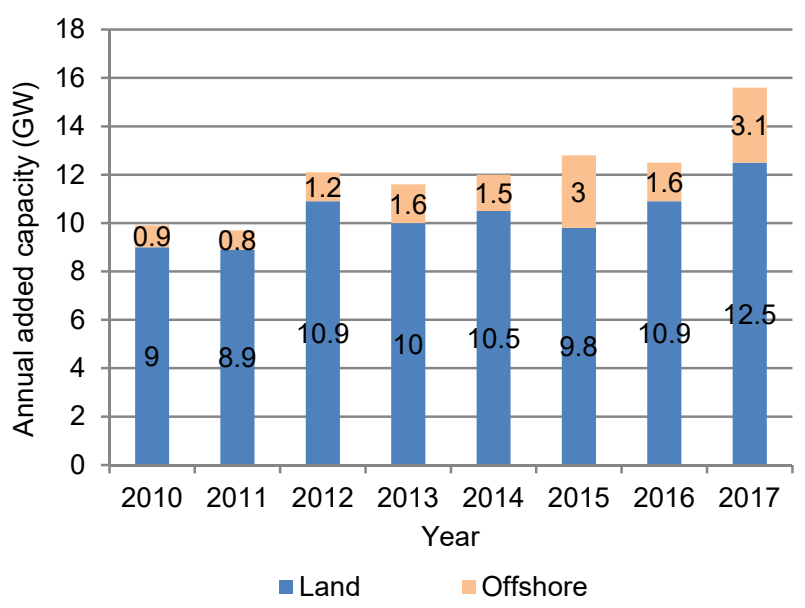

Fig. 2. Annual added capacity of onshore and offshore wind farms in GW at the end of the year in the period 2010-2017 in the EU; source: own elaboration based on WindEurope [2018b]

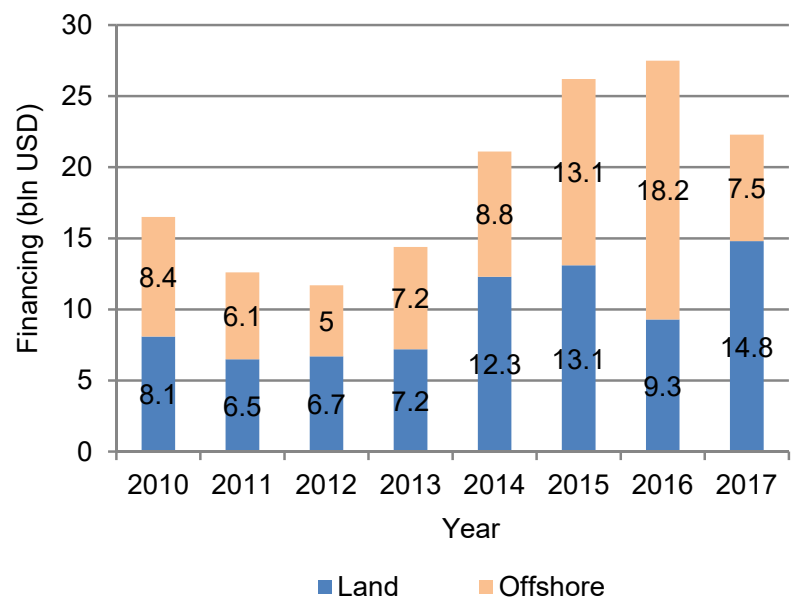

Fig. 3. Financing of new wind investments on land and at sea in 2010-2017 in billions of USD; source: own elaboration based on WindEurope [2018b]

Within the territorial sea, coastal states can build wind farms. This is governed by the United Nations Convention on the Law of the Sea of [1982]. In 2017, 560 new offshore wind turbines were connected to a network of 17 wind farms [PWC 2018]. The leader in terms of installed power at the end of 2017 was the United Kingdom (6 836 MW), followed by Germany (5 355 MW) and China (2 788 MW) as shown in Fig. 4. Large oil and gas companies are also showing their increasing interest in this market. An example of this are the investments of Shell in the Netherlands or the Norwegian energy company Statoil in Great Britain [PWC 2018].

\section{METHODS AND MATERIALS}

The research was conducted based on the analysis of acts, regulations, the subject's literature, information from websites. The techniques of qualitative analysis of documents, and descriptive analysis were used. The basis for the choice of the analysis method was the type of gathered information. 


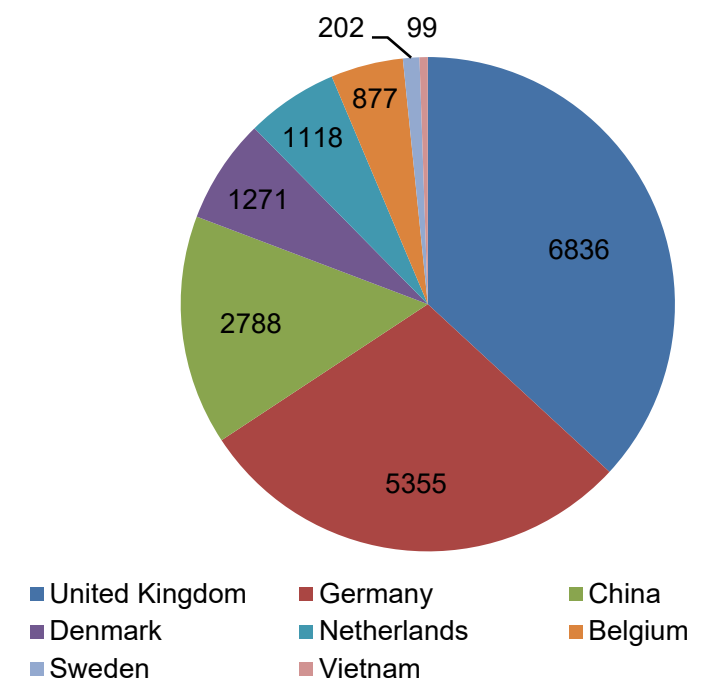

Fig. 4. Total power of offshore wind farms in MW at the end of 2017 in selected countries of the world; source: own study based on GWEC [2017]

\section{RESULTS AND DISCUSSION}

New investments in offshore wind farm financing since 2010 annually amounted to from 5 bln USD (2012) to even 18 bln USD (2016). In 2017, they amounted to 7.5 bln EUR and provided $2.5 \mathrm{GW}$ of power [WindEurope 2018a]. In 2017, a record rise in the installed new capacity of offshore wind farms of $3148 \mathrm{MW}$ can be observed in the EU. At the end of 2017 in five EU countries $98 \%$ of the total capacity of all offshore wind farms located in Europe was installed. The United Kingdom has the largest offshore wind potential in Europe, representing around $43 \%$ of all installations, followed by Germany (around 34\%), followed by Denmark (around 8\%), the Netherlands (around 7\%) and Belgium (around 6\%) [WindEurope 2018a], as shown in Fig. 5. Total capacity of wind farms installed at sea at the end of 2017 in the EU totalled approx. 15.8 GW. At the end of 2017, the United Kingdom had the world's largest offshore wind farm capacity of more than $6.8 \mathrm{GW}$, which war due to approx. 1750 wind turbines, as shown in Figures 5 and 6 . The next state is Germany with the production capacity at approx. 5.4 GW and with around 1170 turbines, then Denmark about $1.3 \mathrm{GW}$ and 500 turbines, the next is the Netherlands with $1.1 \mathrm{GW}$ and over 360 turbines, finally Belgium with approx. $0.9 \mathrm{GW}$ and over 230 turbines. Other countries have a total capacity of about 328 MW and over 125 turbines.

Great Britain has been developing wind energy sector since the 1990s. The power of onshore and offshore wind farms increased from $0.2 \mathrm{GW}$ in 1996 to $18.9 \mathrm{GW}$ in 2017 (Fig. 7). It is also the world's leader in offshore wind energy. The total installed capacity at the end of 2017 was 6.8 GW. The country plans to reach approx. $15 \mathrm{GW}$ of power by 2025 [PWC 2018] and $30 \mathrm{GW}$ by 2030 [WindEurope 2019a], what means that by $203030 \%$ of the UK's electricity is to be provided from offshore wind. Great Britain intends to reduce its carbon dioxide emissions and by 2025 it wants to shut down all coal-fuelled power plants [BŁOŃ-
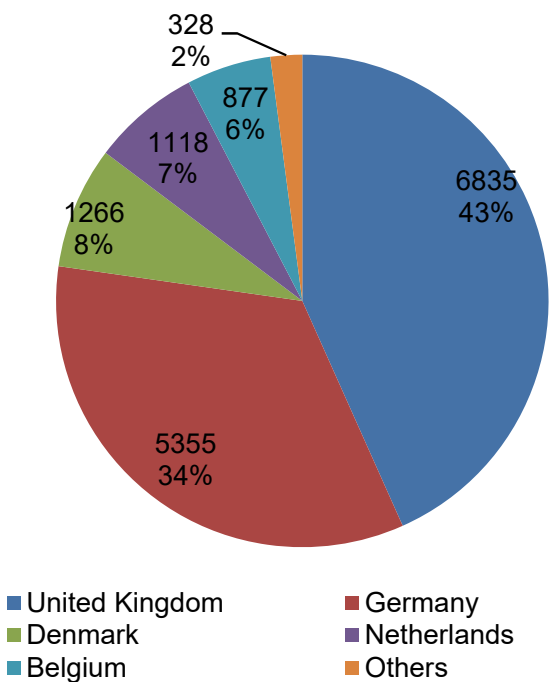

Fig. 5. Total power of offshore wind farms in MW and percentage at the end of 2017 in selected EU countries; source: own study based on GWEC [2017]

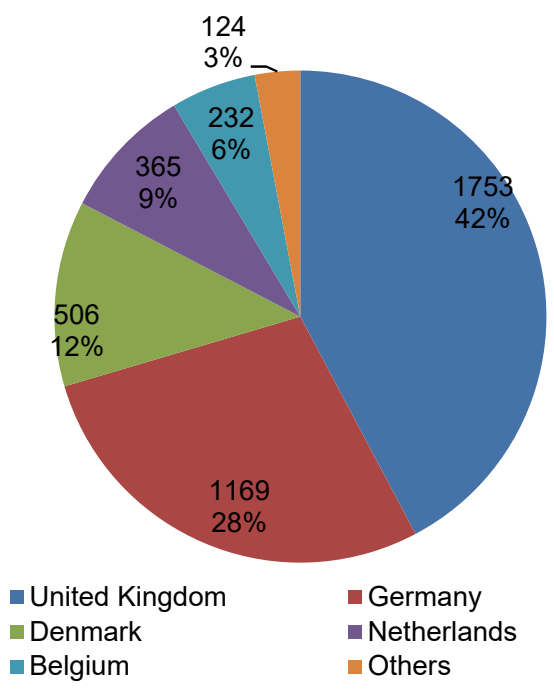

Fig. 6. Total number of turbines at the end of 2017 in selected EU countries; source: own study based on GWEC [2017]

SKI 2017]. The planned total increase in offshore wind farms capacity from 2004 to 2021 is expected to amount to approximately $31 \mathrm{GW}$ (Fig. 8). In 2017, 6 offshore wind farms were launched in Great Britain (Tab. 1). The largest of them are Burbo Bank Extension with the capacity of 200 MW, Rampion with the capacity of 179 MW.

Innovative technological solutions have been applied on the Hywind Scotland offshore wind farm. The turbines are installed in the North Sea at the distance of $24 \mathrm{~km}$ away from the shore. Winds there reach the average speed of 10 $\mathrm{m} \cdot \mathrm{s}^{-1}$ [KULIK 2017]. In total, five turbines have been installed manufactured by the Norwegian Statoil concern. They are 250 high, including $80 \mathrm{~m}$ under the water surface. This is a floating farm attached to the seabed with ropes. It can significantly reduce costs since so far the foundations were built in shallow sea waters [Gramwzielone.pl 2018]. Floating wind turbines can also be installed in waters of 


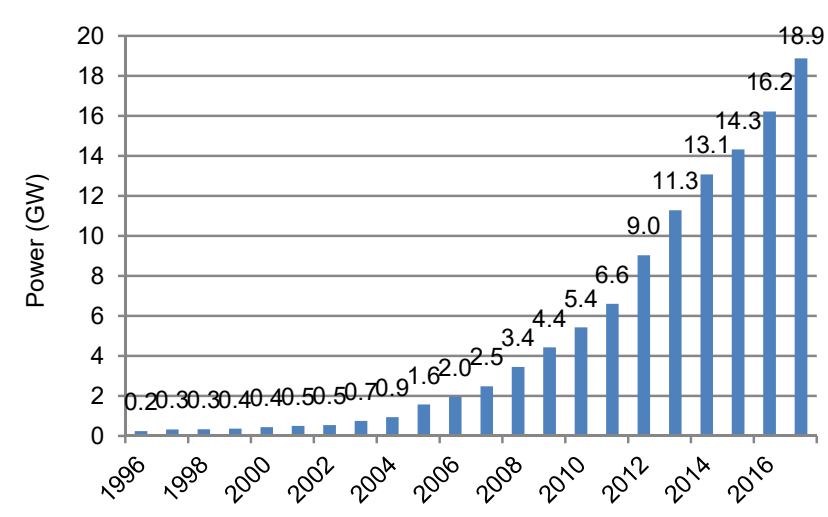

Fig. 7. Power of onshore and offshore wind farms in Great Britain in 1996-2017 at GW; source: own study based on DUKES [2018]

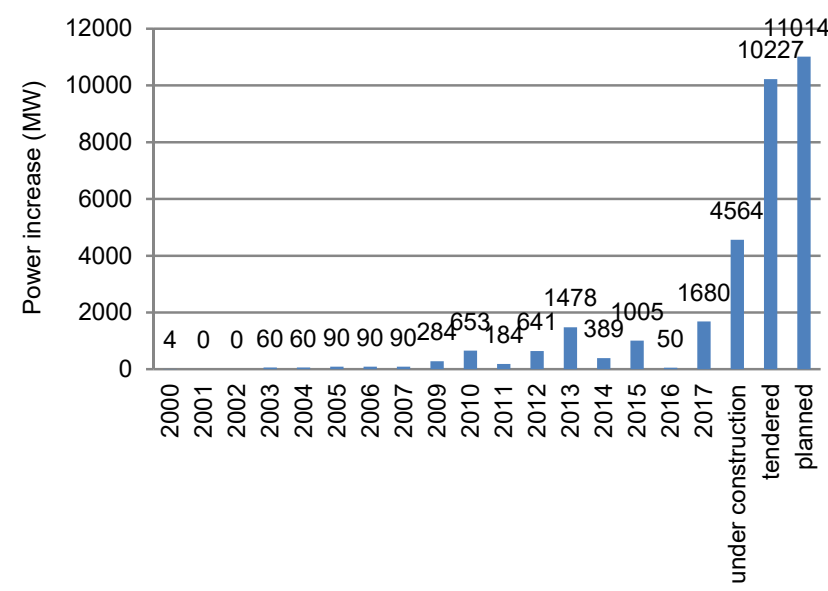

Fig. 8. Power increase of offshore wind farms in Great Britain in 2000-2017, under construction, tender procedure pending and planned until 2021 in MW; source: own study based on DUKES [2017] and PWC [2018]

greater depth, which allows for a full use of the potential of this type of area. This also means that the construction of this type of power plant will not be limited only to places where the depth of the sea does not exceed $50 \mathrm{~m}$. The Hywind farm floats on the water in the place where there is as much as $129 \mathrm{~m}$ to the bottom [STRADECKA 2017]. The technology used for this investment allows the installation of wind turbines in places where the depth reaches up to
$800 \mathrm{~m}$. According to the data provided by Statoil as much as $80 \%$ of locations off the coast of Scotland, with the best conditions for using wind energy, are situated in waters with a depth of over $60 \mathrm{~m}$ [STRZAŁKOWSKI, CIOBANU 2017]. Such a location - in deeper waters, also does not arouse the residents' opposition because it has no negative impact on the landscape.

Currently, there are 4 huge wind farms under construction (Tab. 2). They are all situated in the North Sea. The largest of them is Hornsea Project One with the capacity of 1218 MW situated in Yorkshire in the North-East England. The number of turbines is 174 , each with the capacity of $7 \mathrm{MW}$ and the height of approx. $200 \mathrm{~m}$. The rested windmills are installed at a depth of about $23-27 \mathrm{~m}$ at a distance of about $115 \mathrm{~km}$ from the shore within the area of $407 \mathrm{~km}^{2}$. The construction cost is around 3 bln GBP. Other wind farms are being built as well. Beatrice wind farm with the capacity of $588 \mathrm{MW}$ is situated in Highland on the NorthWest shore of Scotland. The number of turbines is 84 , each with the capacity of $7 \mathrm{MW}$ and the height of approx. 198 $\mathrm{m}$. The rested windmills are installed at a depth of about $35-55 \mathrm{~m}$ at a distance of about $19 \mathrm{~km}$ from the shore within the area of $131 \mathrm{~km}^{2}$. The construction cost is around 2.6 bln GBP. In the North-East of England East Anglia ONE offshore wind farm is being built with the capacity of 714 MW. The number of turbines is 102 , each with the capacity of $7 \mathrm{MW}$ and the height of approx. $197 \mathrm{~m}$. The rested windmills are installed at a depth of about $30-42 \mathrm{~m}$ at a distance of about $55 \mathrm{~km}$ from the shore within the area of $205 \mathrm{~km}^{2}$. The construction cost is around $2.6 \mathrm{bln}$ GBP. Aberdeen Offshore Wind with the capacity of 93.2 MW is being built in the North-East of Scotland. The number of turbines is 11 , each with the capacity of $8.4 \mathrm{MW}$ and the height of approx. $191 \mathrm{~m}$. The rested windmills are installed at a depth of about $20-30 \mathrm{~m}$ at a distance of about $3 \mathrm{~km}$ from the shore within the area of $19 \mathrm{~km}^{2}$. The construction cost is around 3.35 bln GBP, as shown in Table 1. The construction of the largest farm so far named Hornsea Project Two with the capacity of $1386 \mathrm{MW}$, situated near Hornsea Project One, has been approved. The number of turbines is 174 , each with the capacity of $8 \mathrm{MW}$ and the height of approx. $200 \mathrm{~m}$. The rested windmills are installed at a depth of about $30-40 \mathrm{~m}$ at a distance of about $100 \mathrm{~km}$ from the shore within the area of $462 \mathrm{~km}^{2}$. The construction cost is around 6 bln GBP.

Table 1. Farms under construction in Great Britain

\begin{tabular}{|c|c|c|c|c|c|}
\hline Parameter & $\begin{array}{c}\text { Aberdeen Offshore } \\
\text { Wind }\end{array}$ & Beatrice & East Anglia ONE & Hornsea Project One & $\begin{array}{l}\text { Hornsea Project Two } \\
\text { (project approved) }\end{array}$ \\
\hline Location & $\begin{array}{c}\text { Scotland, Grampian } \\
\text { North Sea }\end{array}$ & $\begin{array}{c}\text { Scotland, Highland } \\
\text { North Sea }\end{array}$ & $\begin{array}{c}\text { East England, North } \\
\text { Sea }\end{array}$ & $\begin{array}{c}\text { England, Yorkshire, } \\
\text { North Sea }\end{array}$ & $\begin{array}{c}\text { England, Yorkshire, } \\
\text { North Sea }\end{array}$ \\
\hline Farm's capacity (MW) & 93.2 & 588 & 714 & 1218 & 1386 \\
\hline Turbine's capacity (MW) & 8.4 & 7 & 7 & 7 & 8 \\
\hline Number of turbines & 11 & 84 & 102 & 174 & 174 \\
\hline Total height of windmill (m) & 191 & 198,4 & 197 & 200 & 200 \\
\hline Area $\left(\mathrm{km}^{2}\right)$ & 19 & 131 & 205 & 407 & 462 \\
\hline Depth (m) & $20-30$ & $35-55$ & $30-42$ & $23-37$ & $30-40$ \\
\hline Distance from shore $(\mathrm{km})$ & 2.8 & 18.8 & 55.2 & 114.5 & 100 \\
\hline
\end{tabular}

Source: own study based on 4C Offshore [2018]. 
Table 2. Wind farms launched in Great Britain in 2017

\begin{tabular}{|l|c|c|l|}
\hline \multicolumn{1}{|c|}{ Name of wind farm } & $\begin{array}{c}\text { Year } \\
\text { of commissioning }\end{array}$ & $\begin{array}{c}\text { Capacity } \\
\text { (MW) }\end{array}$ & \multicolumn{1}{|c|}{ Status } \\
\hline Burbo Bank Extension & 2017 & 200 & complete \\
\hline Rampion & 2017 & 179 & partial \\
\hline Galloper & 2017 & 72 & partial \\
\hline Blyth & 2017 & 42 & complete \\
\hline Hywind Scotland & 2017 & 30 & complete \\
\hline Walney 3 & 2017 & 256 & partial \\
\hline
\end{tabular}

Source: own study based on 4C Offshore [2018].

The development of the offshore renewable industry in Great Britain has been accompanied by changes in permit systems and implementation of regulations. They were aimed at facilitating the development of significant on the national scale infrastructure projects. The act about planning [Planning Act 2008] introduced a new permit system for the construction of offshore wind farms with a capacity exceeding $100 \mathrm{MW}$. The entire project planning process is supervised by a single authority. This makes it possible to improve the decision-making process when granting permit for such projects (Offshore Consents \& Licensing). The Government - the Ministry of Energy (DECC) prepares relevant regulations, estimates the size of necessary generation capacities that will be purchased within the power mark, as well as the rules for conducting tenders for production capacity. The British Office of Gas and Electricity Markets (OFGEM) is tasked with analysing the legal regulations and, if necessary, proposing them to change. In case of problems and threats, it reports to the Ministry of Energy. The energy security assessment of the country, power reserves are analysed jointly with the grid operator (National Grid) and energy companies, expert groups. They develop solutions to emerging energy problems. The co-operation between central offices, grid operators and energy companies makes it possible to conduct an efficient and well-coordinated energy policy [MIELCZARSKI 2015].

In Great Britain, Crown Estate is the legal owner and administrator of the seabed, including areas designated for the construction of offshore wind farms. It is responsible for providing a geological model of the bottom and for managing the contracts of a given zone at sea. Developers can register on one or several selected locations. A consortium with the best and cheapest plan is granted the right to develop an offshore wind farm. The winner of the tender is granted a lease of a zone for the construction of wind farms. When the farm starts operating, it pays lease charges to Crown Estate. A special entity, the electricity settlements operator (Electricity Settlements Co.) makes settlements and pays to producers who supply power reserves purchased during the auction. In addition, another entity (Elexon) collects the necessary data for the billing operator. Access to the project support mechanism is an important factor for developers. The support system operates for a period of 15-20 years depending on the conditions announced in the tender. In 2010, the last tender for over $30 \mathrm{GW}$ of power took place [PWC 2018]. Offshore Transmission is responsible for connecting offshore wind farms to the grid.
Great Britain is also becoming one of the European leaders in the implementation of industrial energy storage technologies. Operators across Europe are investing in energy storage. At the end of 2014, the British launched the largest installation of this type on our continent. The facility in Leighton Buzzard near London is able to store up to $10 \mathrm{MWh}$ of energy and provide $6 \mathrm{MW}$ of power. Many companies took part in the implementation of this project. These included: S \& C Electric, Samsung, UK Power Networks and Younicos [BENNET 2014]. In September 2014 the company Younicos built the first commercial energy storage facility in Europe. It was commissioned in German Schwerin and has the capacity of 5 MW [GŁUCHOWSKI 2015]. Currently, the company is building the largest energy storage facility in the EU. The installation will be constructed in Great Britain at the former coal-fuelled power plant in Barrow-in-Furness. The power of the facility will be 49 MW [Elektroinfo 2017].

Energy storage facilities can accumulate surplus energy from renewable energy sources (RES), which solves the problem of high variability of the being power supplied. An operator with a storage facility could support the energy system, ensuring the continuity of supply when the wind is out or after dusk when RES cease to operate. The production of energy exclusively from renewable sources using this technology would not threaten to destabilise the operation of power systems. Energy storage could also reduce the need to expand conventional power plants in the future. Furthermore, they can be economical. At a time when energy is cheap, it can be collected and re-sold to the network in a period when it is more expensive. During the summit of energy demand in the grid, energy storage facilities enable mitigation of the effects of a possible lack of energy. The use of energy storage can also reduce the need to expand costly grid and prevent the occurrence of energy blocking - serious problems related to the supply of energy to users [AMIN, SCHEWE 2017]. In Great Britain, energy storage operators can also count on support and additional remuneration for frequency response services [CIRE.pl 2017]. Moreover, Great Britain cooperates with other countries in the development of energy interconnections. The British energy network currently has four electricity interconnections with France, the Netherlands, Ireland and Northern Ireland. Their total power is approx. $4 \mathrm{GW}$. Electric power imports currently satisfy $4-5 \%$ of the British demand. The British regulator of the energy sector OFGEM provides financial support for such projects. National Grid is responsible for the construction of four interconnectors, including the longest one in the world (760 $\mathrm{km}$ ) connection to Danish wind farms. At the beginning of 2019, the Nemo interconnector connecting the British energy network with Belgium is to be commissioned, and a year later the interconnector across the English Channel. The British government expects that thanks to the planned expansion, the share of imports via interconnectors in total energy imports will increase by 2025 from the current 6 to 20\% [CZYŻEWSKA 2018]. 


\section{CONCLUSIONS}

Worldwide and in the EU, renewable energy is being promoted confirmed by the fact, that as much as $95 \%$ of the new power in Europe in 2018 was renewable energy $(19.8 \mathrm{GW})$, including $49 \%$ from wind $(10.1 \mathrm{GW})$. A very large development of offshore wind energy is being considered. Investments in offshore wind farms in the period 2010-2017 in Europe amounted to 5 to over 18 bln EUR per year.

Great Britain is the leader in the production of offshore wind energy. In 2017, the produced power totalled approx. $6.8 \mathrm{GW}$, which accounts for $43 \%$ of the EU's share. In 2025, Great Britain plans to reach $15 \mathrm{GW}$. At the end of 2017, Great Britain had approx. 1750 wind turbines. By $2030,30 \%$ of electricity demand is to be met by offshore wind energy. Wind farm construction is in full compliance with strict environmental procedures. The project planning process is supervised by a single authority. Crown Estate is the legal owner and administrator of the seabed responsible for contracts. A consortium with the best and cheapest plan wins the tender. The support system operates for a period of 15-20 years depending on the conditions announced in the tender. Ensuring continuous and reliable electricity supply to users is carried out very efficiently by introducing a new power market that is carefully and long-term planned as well as energy interconnections. The cooperation between the three institutions is decisive: Ministry of Energy (DECC), Energy Regulator (OFGEM) and the grid operator (National Grid).

In Great Britain, in the nearest future, floating wind farms (Hywind - Scotland) and energy storage facilities will play an important role in wind energy.

\section{REFERENCES}

4C Offshore 2018. Database on UK wind farm projects [online]. [Access 20.06.2018]. Available at: https://www.4coffshore. $\mathrm{com} /$ windfarms/windfarms.aspx?windfarmId=UK36

Amin M., Schewe P.F. 2017. Preventing blackouts: Building a smarter power grid [online]. Scientific American. [Access 28.12.2018]. Available at: https://www.scientificamerican. com/article/preventing-blackouts-power-grid/

BENNET P. 2014. 'Europe's largest' grid storage battery trial goes online in UK [online]. Energy Storage News. [Access 02.08.2019]. Available at: https://www.energy-storage.news/ news/europes-largest-grid-storage-battery-trial-goes-onlinein-uk

BŁoŃSKI M. 2017. Wielka Brytania obyła się bez węgla [Great Britain managed without coal [online]. Kopalnia Wiedzy.pl. [Access 28.10.2017]. Available at: http://kopalniawiedzy.pl/ Wielka-Brytania-energia-elektryczna-wegiel,26333

BWE 2017. A bis Z. Fakten zur Windenergie. Von A wie Arbeitsplätze bis $\mathrm{Z}$ wie Ziele der Energieversorgun [A to $\mathrm{Z}$. Facts about wind energy. From $A$ for jobs to $Z$ for goals of energy supply] [online]. BundesVerband WindEnergie. [Access 28.09.2017]. Available at: https://www.wind-energie. de/fileadmin/redaktion/dokumente/publikationen-oeffentlich/ themen/01-mensch-und-umwelt/01-windkraft-vor-ort/bwe a bisz_3-2015_72dpi_final.pdf

CIRE.pl 2017. Brytyjscy operatorzy sieci chca prawa do budowy własnych magazynów energii [British grid operator want the right to build their own energy storage facilities] [online].
Serwis Informacyjny CIRE. Centrum Informacji o Rynku Energii. [Access 29.09.2018]. Available at: https://www.cire. pl/item, 143984,1,0,0,0,0,0,brytyjscy-operatorzy-sieci-chcaprawa-do-budowy-wlasnych-magazynow-energii.html

CZYŻEWSKA E. 2018. Nemo połączy Wielką Brytanię i Belgię [Nemo to connect Great Britain with Belgium] [online]. Biznes Alert. [Access: 20.12.2018]. Available at: http:// biznesalert.pl/nemo-energetyka-wielka-brytania-belgia

DAWID L. 2017a. Chosen problems of wind farms localization in light of new law on investments concerning wind power stations. Infrastructure and Ecology of Rural Areas. No. IV/1/2017 p.1445-1455.

DAwID L. 2017b. German support systems for onshore wind farms in the context of Polish acts limiting wind energy development. Journal of Water and Land Development. No. 34 p. 109-115. DOI 10.1515/jwld-2017-0044.

DAWID L. 2018a. Perspectives on offshore wind farms development in chosen countries of European Union. Journal of Water and Land Development. No. 38 p. 27-34. DOI 10.2478/ jwld-2018-0039.

DAwID L. 2018b. Perspektywy rozwoju morskich farm wiatrowych w Polsce w kontekście wprowadzenia ustaw ograniczających budowę farm wiatrowych na lądzie oraz trendów światowych [Perspectives of offshore wind farm development in Poland in the context of the acts limiting onshore wind farms localisation and world trends]. Przegląd NaukowoMetodyczny Edukacja dla Bezpieczeństwa. Nr 38 p. $552-$ 566.

DUKES 2018. Renewable sources of energy [online]. Digest of UK energy statistics. [Access 25.05.2018]. Available at: https://www.gov.uk/government/statistics/renewable-sourcesof-energy-chapter-6-digest-of-united-kingdom-energystatistics-dukes

Directive 2001/77/EC of the European Parliament and of the Council of 27 September 2001 on the promotion of electricity produced from renewable energy sources in the internal electricity market. EU OJ L 283, 27.10.2001.

Directive 2003/30/EC of the European Parliament and of the Council of 8 May 2003 on the promotion of the use of biofuels or other renewable fuels for transport. EU OJ L 123, 17.05.2003.

Directive 2009/28/EC of the European Parliament and of the Council of 23 April 2009 on the promotion of the use of energy from renewable sources and amending and subsequently repealing Directives 2001/77/EC and 2003/30/EC. EU OJ L 140/16, 05.06.2009.

Elektroinfo 2017. Brytyjczycy i Niemcy zbudują wspólnie największy w Europie magazyn energii. [Great Britain and Germany to build the largest energy storage facility in Europe] [online]. Elektro.info. Nr 7-8. [Access 30.09.2018]. Available at: http://www.elektro.info.pl/aktualnosc/id7580, brytyjczycy-i-niemcy-zbuduja-wspolnie-najwiekszy-w-europiemagazyn-energii

GŁUCHOWSKI M. 2015. Największy w Europie magazyn energii elektrycznej powstał w UK [The largest electric power storage facility built in UK] [online]. BIOMA odnawialne źródła energii. [Access 20.01.2018]. Available at: http://odnawialne zrodlaenergii.pl/marazynowanie-energii-a/item/1434najwiekszy-w-europie-magazyn-energii-elektrycznejpowstal-w-uk

Gramwzielone.pl. 2018. Pływająca farma wiatrowa [Floating wind farm] [online]. [Access: 20.06.2018]. Available at: http:/gramwzielone.pl/energia-wiatrowa/28562/ uruchomiono-pierwsza-plywajaca-farme-wiatrowa

GWEC 2017. Global wind report 2017. Opening up new markets for business [online]. Brussels. Global Wind Energy Council. [Access 10.07.2018]. Available at: http://www. tuulivoi- 
mayhdistys.fi/filebank/1191-GWEC_Global_Wind_Report_ April_2018.pdf

KULIK W. 2017. Pierwsza pływająca farma wiatrowa [First floating wind farm] [online]. [Access 28.09.2018]. Available at: http:/www.benchmark.pl/aktualnosci/hywind-scotlandpierwsza-plywajaca-farma-wiatrowa.html?fd

McKinsey\&Company 2016. Developing offshore wind power in Poland. Outlook and assessment of local economic impact [online]. [Access 02.08.2019]. Available at: http://mckinsey. pl/wp-content/uploads/2016/10/McKinsey_Developingoffshore-wind-power-in-Poland_fullreport.pdf

MiELCZARSKI W. 2015. Brytyjskie doświadczenia z rynków mocy [British experiences of power markets] [online]. Energy NewsLetters. No. 9 [Access 28.07.2018]. Available at: https://www.cire.pl/pliki/2/brytyjskie_doswiadczenia_z_rynk ow_mocy.pdf

Odnawialne-Firmy.pl 2014. Elektrownie wiatrowe offshore wady i zalety [Offshore power plants - pros and cons] [online]. [Access 28.10.2018]. Available at: https://www. odnawialne-firmy.pl/wiadomosci/pokaz/18, elektrowniewiatrowe-offshore-wady-i-zalety

Planning Act 2008. Promotion of Renewable Energy Act no. 1392 of 27 December 2008 [online]. [Access 28.09.2018]. Available at: http://www.legislation.gov.uk/ukpga/2008/29/ contents

PSEW 2016. Stan energetyki wiatrowej w Polsce w 2015 roku [Wind energy in Poland in 2015]. Warszawa. Polskie Stowarzyszenie Energetyki Wiatrowej pp. 11.

PWC 2018. Unlocking Europe's offshore wind potential. Moving towards a subsidy free industry [online]. Amsterdam. PricewaterhouseCoopers B.V. pp. 44. [Access 20.05.2018]. Available at: https://www.pwc.nl/nl/assets/documents/pwcunlocking-europesoffshore-wind-potential.pdf

STRADECKA A. 2017. Hywind Scotland: największa pływająca dalekomorska elektrownia na świecie już otwarta [Hywind Scotland: The largest floating offshore power plant in the world already launched] [online]. [Access 20.06.2018]. Available at: https://magazynt3.pl/hywind-scotland- najwieksza-plywajaca-dalekomorska-elektrownia-na-swieciejuz-otwarta/

Stryjecki M., MielniczuK M., Biegaj J. 2011. Przewodnik po procedurach lokalizacyjnych i środowiskowych dla farm wiatrowych na polskich obszarach morskich [A guidebook to location and environmental procedures for wind farms in Poland's maritime areas]. Warszawa. Fundacja na rzecz Energetyki Zrównoważonej. ISBN 987-83-934100-0-2 pp. 156.

StRZAŁKOWSKi M., CiOBANU V. 2017. Pierwsza pływająca farma wiatrowa na świecie produkuje już prąd u wybrzeży Szkocji [First floating wind farm in the world already generating electricity near the shore of Scotland [online]. [Access 28.11.2018]. Available at: https://www.euractiv.pl/section/ energia-i-srodowisko/news/pierwsza-plywajaca-farmawiatrowa-swiecie-produkuje-juz-prad-u-wybrzezy-szkocji

United Nations Convention on the Law of the Sea 1982 [online]. [Access 25.01.2018]. Available at: http://www.un.org/depts/ los/convention_agreements/texts/unclos/unclos_e.pdf

WindEurope 2018a. Offshore wind in Europe. Wind Europe. Key trends and statistics 2017 [online]. [Access 20.01.2018]. Available at: https://windeurope.org/wpcontent/uploads/files/ about-wind/statistics/WindEurope-Annual-OffshoreStatistics-2017.pdf

WindEurope 2018b. Wind in power 2017. Annual combined onshore and offshore wind energy statistics [online]. [Access 25.01.2018]. Available at: https://windeurope.org/wp-content/ uploads/files/about-wind/statistics/WindEurope-AnnualStatistics-2017.pdf

WindEurope 2019a. Offshore wind to provide 30\% of UK's electricity in new 'Sector Deal' boost [online]. [Access 25.04.2019]. Available at: https://windeurope.org/newsroom/ press-releases/offshore-wind-to-provide-30-percent-of-ukselectricity-in-new-sector-deal-boost/

WindEurope 2019b. Wind energy in Europe in 2018. Trends and statistics [online]. [Access 25.04.2019]. Available at: https://windeurope.org/wp-content/uploads/files/aboutwind/statistics/WindEurope-Annual-Statistics-2018.pdf

\section{Leszek DAWID}

\section{Obecny status i perspektywy rozwoju morskich farm wiatrowych w Wielkiej Brytanii}

\section{STRESZCZENIE}

Celem artykułu było przedstawienie perspektyw rozwoju morskich farm wiatrowych w wiodącym pod tym względem kraju w Unii Europejskiej i na świecie - Wielkiej Brytanii. Energetyka wiatrowa odgrywa istotną rolę w procesie zapewnienia Europie bezpieczeństwa energetycznego, zaspokajając w 2016 r. zapotrzebowanie na energię elektryczną w 10,4\%, a rok później - w 11,6\%. W artykule przeanalizowano moc działających i budowanych farm wiatrowych, systemy wsparcia oferowane przez ten kraj oraz inne kryteria. Badania przeprowadzono na podstawie analizy aktów prawnych, przepisów, literatury przedmiotu oraz informacji ze stron internetowych. W artykule wykazano, że na świecie i w UE promowana jest energia odnawialna, a brytyjski sektor energetyki morskiej charakteryzuje się silnym wsparciem rządu.

Słowa kluczowe: energia wiatrowa, morskie farmy wiatrowe, odnawialne źródła energii, produkcja energii 